\title{
Apilamätä, Fusarium-punahomeet ja juurilaho puna-apilan hävittäjinä
}

\author{
${ }^{1)}$ Tapani Yli-Mattila, ${ }^{2)}$ Galina Kalko, ${ }^{3)}$ Asko Hannukkala, ${ }^{1)}$ Sari Paavanen-Huhtala ja \\ ${ }^{4)}$ Kaija Hakala \\ ${ }^{1)}$ Turun yliopisto, Biologian laitos, Kasvifysiologia ja molekyylibiologia, 20014 Turku \\ tymat@utu.fi \\ ${ }^{2)}$ Yleisvenäläinen Kasvinsuojeluinstituutti, 196608 Pietari,Venäjä, kalko@yahoo.com \\ ${ }^{3)}$ MTT Kasvintuotannon tutkimus/Kasvinsuojelu, 31600 Jokioinen, asko.hannukkala@mtt.fi \\ ${ }^{4)}$ MTT Kasvintuotannon tutkimus/Kasvinviljely, 31600 Jokioinen, kaija.hakala@mtt.fi
}

Apilamätä (Sclerotinia trifoliorum) on ehkä tärkein satotappioiden aiheuttaja puna- ja valkoapilalla Euroopan ja Pohjois-Amerikan pohjoisosissa. Lisäksi monet yleiset maasienet, kuten Fusarium-lajit eli punahomeet, voivat puna-apilalle epäsuotuisissa oloissa aiheuttaa juurilahoa.

Suomessa apilan juurilahoa ja apilamätää on tutkittu niittonurmissa laajemmin viimeksi 1960luvulla. Muissa Pohjoismaissa apilamätäkantojen sukulaisuussuhteita muihin Sclerotiniasuvun lajeihin on tutkittu Norjassa 1990-luvulla, kun taas Ruotsissa on 2000-luvulla tutkittu Fusarium-punahomeiden aiheuttamaa juurilahoa luomu-puna-apilassa.

Tämän tutkimuksen tavoitteena oli selvittää luomuapilapeltojen juurisienikoostumusta verrattuna tavanomaiseen viljelyyn. Lisäksi tutkimme viljasta eristettyjen Fusarium- ja apilamätäkantojen patogeenisuutta puna-apilalla laboratoriokokeissa sekä biologisten torjuntamenetelmien käyttöä apilamätää vastaan.

Apilamädän rihmastopahkat säilyvät vuosikausia elossa maaperässä. Niinpä apilamätäisessä pellossa on monen vuoden ajan suuri tautiriski. Apilanviljellyn romahtamisesta viimeisen 40 vuoden aikana on seurannut se, että apilamätä on hävinnyt laajoilta alueilta varsinkin Etelä- ja Länsi-Suomesta. Pohjoisilla alueilla, esim. Kainuussa apilamätä on yhä vieläkin yleinen.

Toisin kuin apilamätä, Fusarium-punahomeet voivat elää lahottajina maaperässä tai muissa isäntäkasveissa, kun puna-apilaa ei ole pellossa, joten ne ovat vähemmän riippuvaisia punaapilasta. Erilaisten taudinaiheuttajien lajistoa analysoitiin Jokioisissa siirtymävaiheen luomupellolla, Juvalla luomupellolla sekä kahdella tavanomaisesti viljellyllä apilapellolla Marttilassa. Gliocladium-, Trichoderma- ja Rhizoctonia-isolaatteja löytyi enemmän vanhoista kuin nuorista luomuapilapelloista, kun taas nuoremmista pelloista löytyi enemmän Cylindrocarpon-isolaatteja. Tavanomaisesti viljellyillä pelloilla oli runsaammin Fusarium avenaceum- ja $F$. culmorum-punahomeita ilmeisesti seurauksena apilaa edeltäneestä viljanviljelystä. Kuitenkin vain yksi tutkituista 14 punahomeisolaatista aiheutti tautioireita puna-apilan siementaimilla. Useiden punahome- ja apilamätäkantojen tunnistus varmistettiin ja $F$. avenaceum-punahomeen isolaattien sukulaisuussuhteita tutkittiin DNA-analyyseillä.

Vuosina 2003-2004 tekemässämme tutkimuksessa apilamätää tavattiin vain Pohjois-, Itä- ja Kaakkois-Suomessa, vaikka se 1960-luvulla oli yleinen kaikkialla Suomessa. Aggressiivisin apilamätäkanta löytyi Lapista. Apilalajikkeiden välillä oli eroja apilamätäherkkyydessä. Bjursele-lajiketta on aiemmin pidetty kestävimpänä puna-apilalajikkeena apilamätää vastaan. Laboratoriokokeissa Bjursele ja siitä polveutuva Betty olivatkin Jokioinen- ja Ilte-lajikkeita kestävämpiä. Yksi tutkituista biopreparaateista, venäläinen "Alirin", osoittautui jonkin verran tehokkaaksi apilamätää vastaan laboratoriokokeissa. Tulos oli vaatimaton parin viikon viive apilamädän tuhossa, mutta se antaa viitteitä siitä, että biopreparaateilla saattaa olla tehoa apilamätää vastaan myös kenttäoloissa, jos tehokas preparaatti onnistutaan löytämään.

Asiasanat: DNA, luomu, Sclerotinia trifoliorum, biologinen torjunta 


\section{Johdanto}

Apilamätä (Sclerotinia trifoliorum) on ehkä tärkein satotappioiden aiheuttaja puna- ja valkoapilalla Euroopan ja Pohjois-Amerikan pohjoisosissa. Apilamätä iskeytyy yleensä nuoriin, hyväkuntoisiin apilanurmiin. Apilamädän on havaittu leviävän pelloilla ja iskeytyvän apiloihin vielä $0{ }^{0} \mathrm{C}: \mathrm{n}$ lämpötilassa, joka on huomattavasti sienirihmaston kasvun optimilämpötilan alapuolella. Apilanmätää voidaan torjua käyttämällä taudinkestäviä lajikkeita. Kemikaalejakin on kokeiltu, jopa menestyksellä syksyisin ennen lumentuloa (Ylimäki, 1969), mutta esim. Kemira-growhow ei voi tällä hetkellä suositella mitään kemiallista valmistetta apilamätää vastaan.

Juurilaho tuhoaa apilan juuria jo taimiasteelta alkaen. Monet yleiset maasienet, kuten Fusarium-lajit eli punahomeet, voivat puna-apilalle epäsuotuisissa oloissa aiheuttaa juurilahoa. Vanhenevissa kasvustoissa on niittojen yhteydessä syntyneitä mekaanisia vaurioita. Ne tarjoavat monille maassa eläville taudinaiheuttajille helpon pääsyn kasvien juuristoon. Oireet vaihtelevat riippuen taudin aiheuttajista, isäntäkasveista ja ympäristöoloista. Tauti johtaa juurien johtosolukon vioittumiseen ja lopulta sen tuhoutumiseen. Sienirihmastojen tukkiessa johtosolukkoja apilan aineenvaihdunta häiriintyy ja kasvit näivettyvät vähitellen. Johtosolukon tuhouduttua sienet tunkeutuvat ympärilläkin oleviin solukkoihin ja lahottavat ne. Juurien lahoamista tapahtuu kaikkina vuodenaikoina, mutta selvimmät tuhot havaitaan keväällä, jolloin kasvit ovat talven heikentämiä (Ylimäki, 1967).

Suomessa apilan juurilahoa ja apilamätää on tutkittu niittonurmissa laajemmin viimeksi 1960-luvulla (Ylimäki 1967, 1969). Muissa Pohjoismaissa apilamätäkantojen sukulaisuussuhteita muihin Sclerotinia-suvun lajeihin on tutkittu Norjassa 1990-luvulla (Holst-Jensen ym., 1998), kun taas Ruotsissa on 2000-luvulla tutkittu Fusariumpunahomeiden aiheuttamaa juurilahoa luomu-puna-apilassa (Wallenhammar ym., 2005).

Tämän tutkimuksen tavoitteena oli selvittää luomuapilapeltojen juurisienikoostumusta verrattuna tavanomaiseen viljelyyn. Apilan taudinaiheuttajia tunnistettiin nyt ensi kerran DNA-menetelmien avulla. Lisäksi tutkimme viljasta eristettyjen Fusarium- ja apilamätäkantojen patogeenisuutta puna-apilalla laboratoriokokeissa sekä biologisten torjuntamenetelmien käyttöä apilamätää vastaan. Työn alustavia tuloksia on esitetty Ruotsissa NJF-seminaarissa kesällä 2005 (Yli-Mattila ym., 2005).

\section{Aineisto ja menetelmät}

\section{Sieni-isolaattien eristäminen ja tunnistaminen}

Sieni-isolaatit eristettiin pintasteriloiduista (1\% hypokloriitti $5 \mathrm{~min}$ ) puna-apilan juurista vuosina 2003-2004. Näytteet kerättiin, Jokioisissa siirtymävaiheen luomupellolta, Juvalla luomupellolta sekä Marttilassa kahdelta tavanomaisesti viljelyltä apilapellolta. Apilamätäisolaatit eristettiin $70 \%$ etanolilla pintasteriloiduista rihmastopahkoista, joita kerättiin Rovaniemeltä, Sotkamosta ja Juvalta kenttäkokeista, joissa apilamätä oli tuhonnut punaapilaa. Puhdasviljelmien tunnistus tehtiin makro- ja mikroskooppisten tuntomerkkien perusteella. DNA-eristykset, ITS (internal transcribed spacer)-sekvensoinnit ja näin saatujen DNA-sekvenssien vertailut tunnettuihin ITS-sekvensseihin lajien tunnistuksen varmistamiseksi tehtiin Yli-Mattila ym. (2004) mukaisesti. F. avenaceum-kantojen tunnistus varmistettiin lajispesifisillä DNA-alukkeilla (Yli-Mattila ym., 2004) Kymmenellä $F$. avenaceum-kannalla tehtiin myös RAPD-PCR-analyysi (Yli-Mattila ym., 1996, PaavanenHuhtala ym., 1999).

\section{Puna-apilalajikkeet}

Työn laboratorio-osuudessa tutkittiin neljää puna-apilalajiketta. Näistä diploidi Jokioinen on kotoisin Suomesta, tetraploidi Ilte Virosta ja diploidi Bjursele ja siitä kehitetty tetraploidi Betty Ruotsista. Tetraploidit lajikkeet ovat satoisampia kuin diploidit lajikkeet, ja Betty on lisäksi huomattavasti talvenkestävämpi kuin muut nyt tutkitut lajikkeet (Hakala \& Jauhiainen 2006, Maatilan Pirkka 2/2000). 
Puna-apilasaastutukset, resistenssikokeet sienillä ja biopreparaattien tehokkuuden testaus Puna-apilan siemenet pintasteriloitiin $0,1 \% \mathrm{AgNO}_{3}$-liuoksella minuutin ajan, minkä jälkeen ne huuhdeltiin steriilillä vedellä. Fusarium-itiöitä tuotettiin Petri-maljoilla kasvatetuilla puhdasviljelmillä Yli-Mattila ym. (2005) mukaisesti. Steriloidut apilan siemenet käsiteltiin itiösuspensioilla $\left(2,5 \times 10^{5}-10^{6}\right.$ itiötä/ml $) 10$ min ajan. Tämän jälkeen siemenet kuivattiin ja laitettiin suodatinpaperille Petri-maljoille. Kokeet tehtiin neljänä toistona (50 siementä per Petri-malja) jatkuvassa valossa 24 asteen lämpötilassa. Tulokset tarkastettiin kahden viikon kuluttua. Seitsemän Fusarium-kannan patogeenisuutta tutkittiin sekä Bjursele- että Jokioinenlajikkeella, ja sen jälkeen vielä seitsemän kannan patogeenisuutta tutkittiin Jokioinenlajikkeella. Patogeenisuutta arvioitiin itämisen perusteella.

Apilamädästä tuotettiin rihmastonpaloja sisältävä suspensio mukaellen Marum ym. (1994) menetelmää. Irti leikattuihin apilan lehtiin (kaikki neljä lajiketta), jotka oli sijoitettu $0,5 \%$ vesi-agarille (joka sisälsi $50 \mathrm{mg} / \mathrm{l}$ bentsimidatsolia) pipetoitiin homogenoituja rihmastonpaloja sisältävä $10 \mu \mathrm{l}: n$ ymppi ja lehtiä pidettiin $15^{\circ} \mathrm{C}: n$ lämpötilassa 12 tunnin valo-pimeäsyklissä 10-14 vuorokauden ajan. Ymppi valmistettiin viikon ikäisestä PDnesteviljelmästä ja lopullista rihmastonpalasuspension konsentraatio säädettiin spektrofotometrin avulla (absorptio 1,2 $647 \mathrm{~nm}: n$ aallonpituudella). Ymppäyksessä käytettiin kolmea apilamätäkantaa, Rovaniemen, Kainuun ja Juvan. Lehdistä arvioitiin oireet: $0=$ terve lehti, 1 = lievä tauti, $2=$ keskinkertainen tauti, $3=$ voimakas tauti ja $4=$ kuollut lehti. Biopreparaattien tehokkuutta apilamätää vastaan tutkittiin Bjursele- lajikkeen neljän viikon ikäisillä kasveilla kasvatuskammiossa. Saastutus tehtiin ruiskuttamalla rihmastonpaloja sisältävää homogenaattia kasveihin, minkä jälkeen kasvit laitettiin $100 \%$ :n kosteuteen. Biopreparaatit ja kemialliset torjunta-aineet ruiskutettiin kasveihin vuorokautta ennen saastutusta käyttäen valmistajien suosittamia pitoisuuksia. Kasvit arvioitiin asteikolla 0 (terve kasvi) - 4 (kuollut kasvi) kahden ja neljän viikon kuluttua saastutuksesta.

\section{Tulokset ja tulosten tarkastelu}

\section{Juurilaho}

Alustavien tulosten mukaan Fusarium avenaceum oli yleisin punahome varsinkin tavanomaisesti viljellyillä pelloilla. Fusarium culmorum-punahometta löytyi ainoastaan tavanomaisesti viljellyillä pelloilla, kun taas Rhizoctonia solani, joka aiheuttaa juurilahoa apilalla, oli yleisempi luomupelloilla. Jokioisten siirtymävaiheen luomupellolla puolestaan oli suhteellisen runsaasti Cylindrocarpon-hometta.

\begin{tabular}{|c|c|c|c|c|}
\hline \multirow{2}{*}{$\begin{array}{l}\text { Morfologinen } \\
\text { tunnistus }\end{array}$} & \multirow[t]{2}{*}{ Koodi } & \multicolumn{3}{|c|}{ Molekyylibiologinen tunnistus } \\
\hline & & JIA & AA & ITS \\
\hline $\begin{array}{l}\text { Cylindrocarpon } \\
\text { sp. }\end{array}$ & $\mathrm{A} 1 / 2$ & - & & $\begin{array}{l}\text { Cylindrocarpon destructans/Neonectria } \\
\text { radicicola }\end{array}$ \\
\hline $\begin{array}{l}\text { Fusarium } \\
\text { avenaceum }\end{array}$ & $\mathrm{A} 4 / 2$ & + & & \\
\hline F. avenaceum & $3 *$ & + & & Fusarium avenaceum/F.tricinctum \\
\hline F. avenaceum & VT5/1 & - & & \\
\hline Alternaria sp. & A4/1 & - & + & \\
\hline Alternaria sp. & $\mathrm{A} 3 / 1$ & - & - & \\
\hline F.avenaceum & VT4/3 & - & & Fusarium avenaceum/F.tricinctum \\
\hline & $5 ; 2$ & - & & \\
\hline $\begin{array}{l}\text { Rhizoctonia } \\
\text { solani/F. } \\
\text { avenaceum }\end{array}$ & $6 / 2 ; 2 *$ & + & & \\
\hline Mucor sp. & $8 / 2 ; 1$ & - & & Mucorsp. \\
\hline
\end{tabular}

Taulukko 1. Esimerkkejä sieni-isolaateista, joiden morfologinen tunnistus varmistettiin lajispesifisillä alukkeilla JIA (spesifinen $F$. avenaceum-punahomeelle) ja AA (spesifinen Alternaria alternata-homeelle) sekä ITS-sekvenssien avulla. 
Mielenkiintoista oli Gliocladium- ja Trichoderma-homeiden suuri määrä Juvan luomupellolla. Näihin homeisiin kuuluu useita lajeja, joita käytetään tautihomeiden biologisessa torjunnassa. Siten ne antavat puna-apilalle luontaista vastustuskykyä. Luomupellolla näyttäisikin siis olevan luontaista torjuntakykyä juurilahoa vastaan. (Kuva 1).

ITS-sekvenssien avulla voitiin varmistaa apilamätäkantojen lajimääritykset. Ne myös tukivat sukutasolla Fusarium-, Cylindrocarpon- ja Mucor-sukujen lajimäärityksiä (Taulukko 1). Lajispesifisillä alukkeilla voitiin puolestaan varmistaa $F$. avenaceum- ja Alternaria alternataisolaattien lajimääritys sekä se, että Rhzoctonia solani-rihmasto sisälsi myös $F$. avenaceumrihmastoa (Taulukko 1). Vain yksi tutkituista 14 Fusarium-isolaateista oli patogeeninen apilan siementaimille (Kuva 2). Patogeenisten isolaattien pieni määrä verrattuna aiempaan tutkimukseen (Ylimäki, 1967) johtuu ilmeisesti siitä, että aiemman tutkimuksen sieni-isolaatit olivat peräisin selvästi sairaista kasveista, kun taas nyt tehdyssä tutkimuksessa Fusariumisolaatit olivat peräisin oireettomista kasveista.

DNA-analyysin (RAPD-PCR) avulla kaikki tutkitut 20 Fusarium-isolaattia voitiin erottaa toisistaan isolaateille spesifisten monistustuotteiden avulla. Kymmenen tutkittua $F$. avenaceum-isolaattia jakaantuivat UPGMA-sukupuussa kahteen pääryhmään, joista löytyi edustajia eri kasvupaikoista.

\begin{abstract}
Apilamätä
DNA-analyysin (RAPD-PCR) perusteella kolmesta eri paikasta kerätyt apilamätäkannat olivat lähes samanlaisia keskenään. ITS-sekvenssien perustella ne kaikki kuuluvat Sclerotinia trifoliorum-lajiin (Kuva 3) Alustavien saastutuskokeiden perusteella ne kaikki olivat myös hyvin aggressiivisia. Kantojen samankaltaisuus saattaisi johtua siitä, että rihmastopahkoista kasvavat rihmastot voivat Pohjoismaissa saastuttaa apilaa myös suoraan ilman itiöemävaihetta ja rihmastopahkat voivat levitä kylvösiemenen mukana.

apilanviljellyn romahtamisesta viimeisen 40 vuoden aikana on seurannut se, että apilamätä on hävinnyt laajoilta alueilta varsinkin Etelä- ja Länsi-Suomesta.

Apilalajikkeista Bjursele ja Betty olivat vastustuskykyisempiä apilamätäkantaa Juva2 vastaan kuin Jokioinen ja Ilte. Mikään kanta ei ollut vastustuskykyinen kahta muuta pohjoissuomalaista kantaa vastaan (Kuva 5). Vain yksi tutkituista neljästä biopreparaatista hidasti taudin kehittymistä ja kasvien kuolemista kasvihuonekokeissa (Taulukko 2).
\end{abstract}

\title{
Johtopäätökset
}

Luomuviljelyllä näyttäisi olevan tulostemme perusteella vaikutusta apilanjuurten sienilajikoostumukseen. Luomupelloilta löytyi mm. Gliocladium- ja Trichoderma-homeita, jotka antavat puna-apilalle luontaista vastustuskykyä. Jatkossa on tutkittava luomupeltojen apilajuurten sienilajikoostumusta ja sen vaikutusta juurilahon kehittymiseen useammalla luomupellolla. Apilamätä aiheutti ongelmia Itä- ja Pohjois-Suomen apilanurmilla vuosina 2003-2005. Myös Etelä- ja Länsi-Suomessa tilannetta pitää seurata luomupelloilla, joilla puna-apilaa viljellään säännöllisesti. Ainakin yhdellä tutkitulla biopreparaatilla näyttäisi olevan mahdollista hidastaa apilamädän kehitystä puna-apilassa. Jatkossa on tutkittava useampia biopreparaatteja, minkä jälkeen biopreparaattien vaikutusta apilamätää vastaan on tutkittava kenttäkokeissa, joissa apila kasvaa talvella lumen alla. Tavoitteena on saada aikaan niin suuri taudin kehittymisen hidastuminen, että riittävästi luomuapilaa säilyisi talven yli niittonurmilla. Myös apilamädälle kestävämpien apilalajikkeiden etsimistä ja jalostustyötä on jatkettava. 
2003

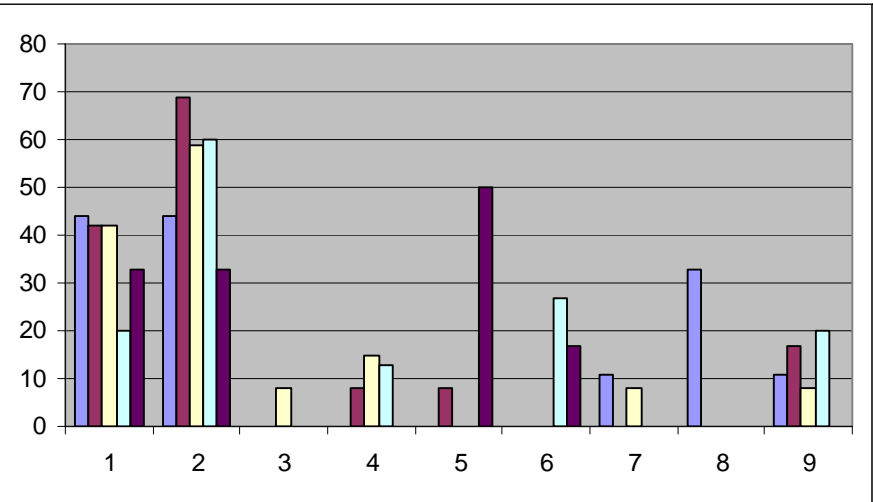

2004

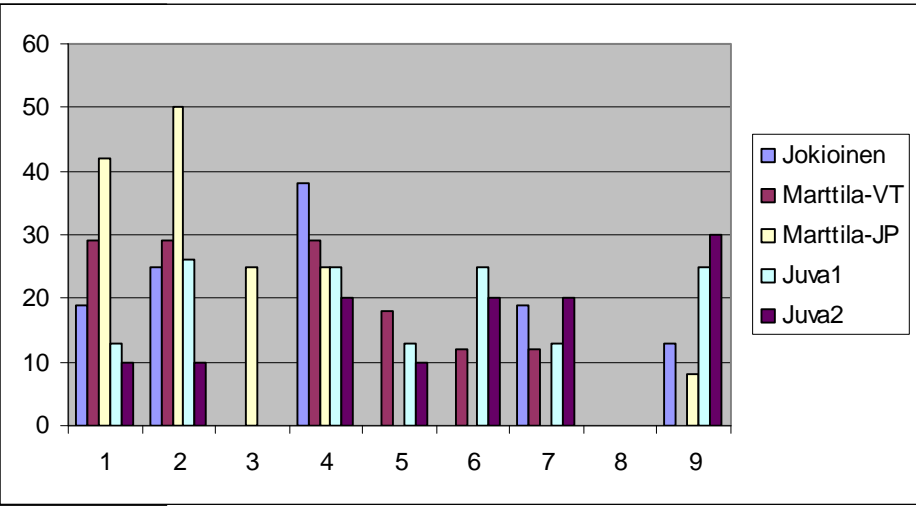

Kuva 1. Eri sienilajien suhteelliset määrät puna-apilan juurissa kuivana ja lämpimänä kasvukautena 2003 ja sateisena kasvukautena 2004 siirtymävaiheen luomupellolla Jokioisilla, kahdella tavanomaisesti viljellyllä pellolla Marttilassa sekä ensimmäisen ja toisen vuoden luomupellolla Juvalla. $1=$ Fusarium avenaceum, $2=F$. avenaceum $/ F$. tricinctum $/ F$.acuminatum, $3=F$. culmorum, $4=$ muut $F$ usarium-lajit, $5=$ Gliocladium $/$ Trichoderma, $6=$ Rhizoctonia, $7=$ Cylindrocarpon, $8=$ Alternaria, $9=$ muita sieniä
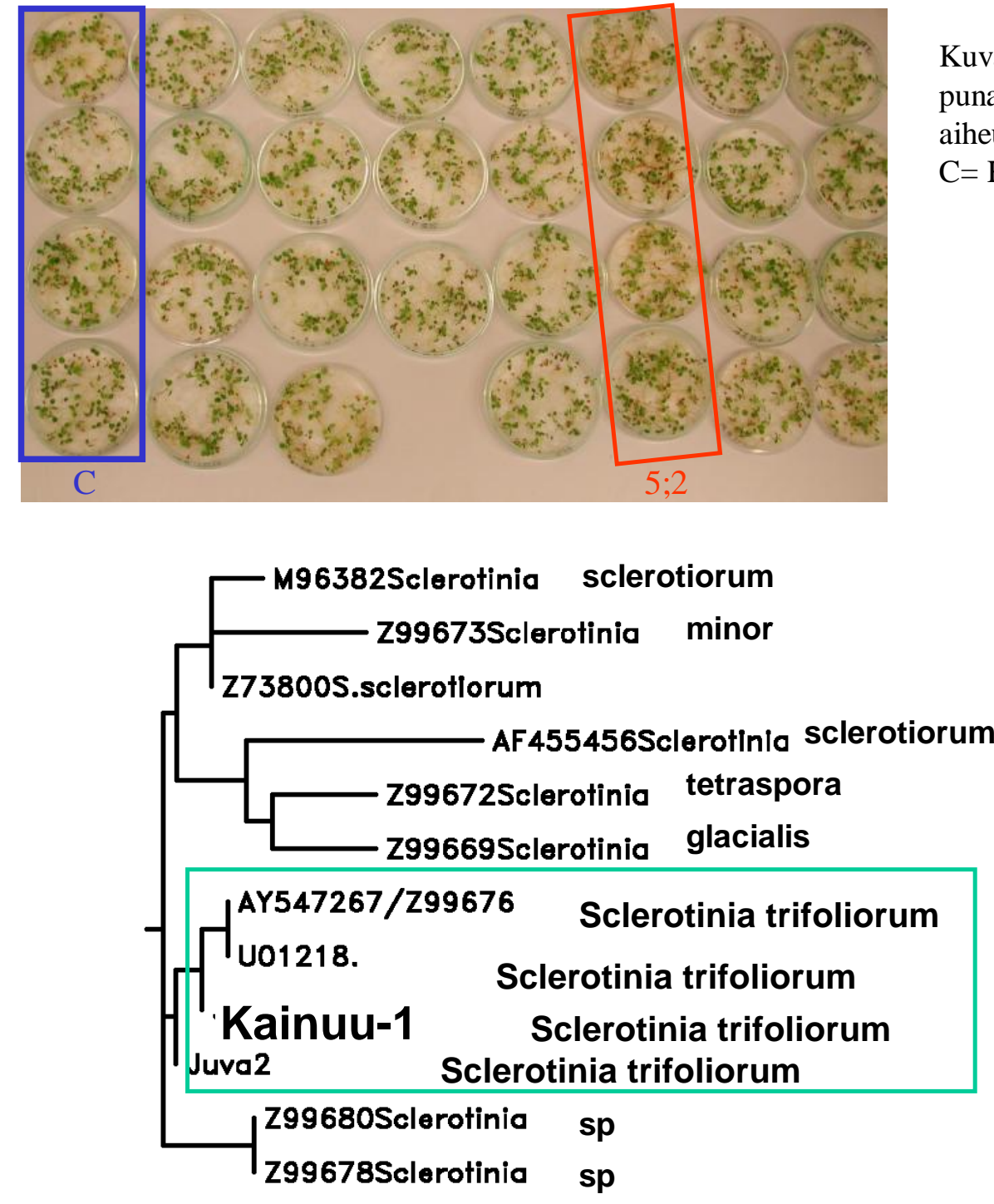

Kuva 2. Eri Fusarium-kantojen patogeenisuus puna-apiloiden siementaimiin. Vain kanta 5;2 aiheutti oireita (ruskea väri) siementaimiin. $\mathrm{C}=$ Kontrolli.
Kuva 3. ITS-sekvensseihin perustuva UPGMA-sukupuu. Suomalaiset apilamätäisolaatit ryhmittyvät tunnettujen $S$. trifoliorum-isolaattien kanssa 


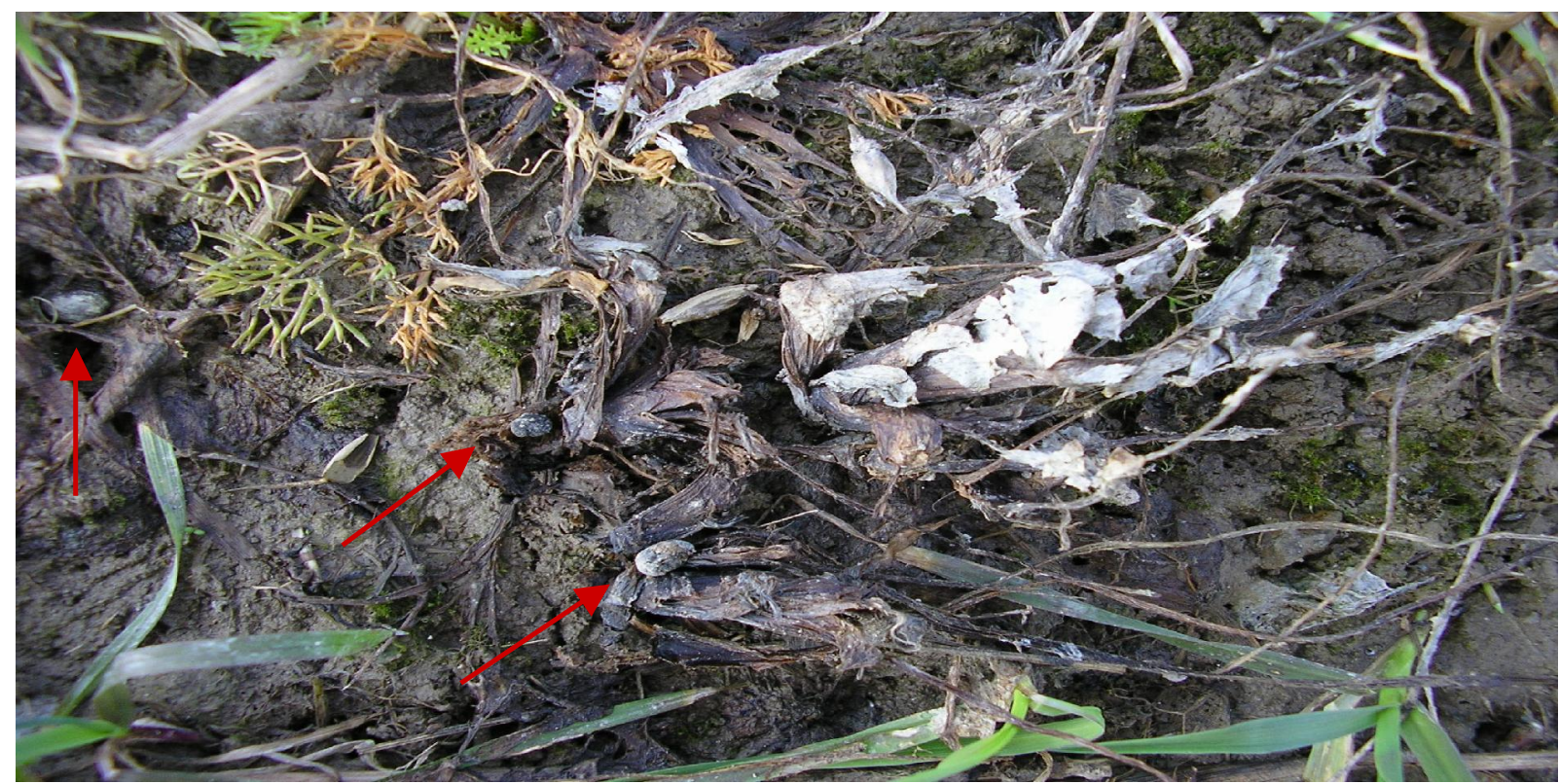

Kuva 4. Apilamädän tuhoamaa apilaa ja rihmastopahkoja (osoitettu punaisilla nuolilla) kenttäkokeissa Kainuussa (kuva Jukka Kemppainen)

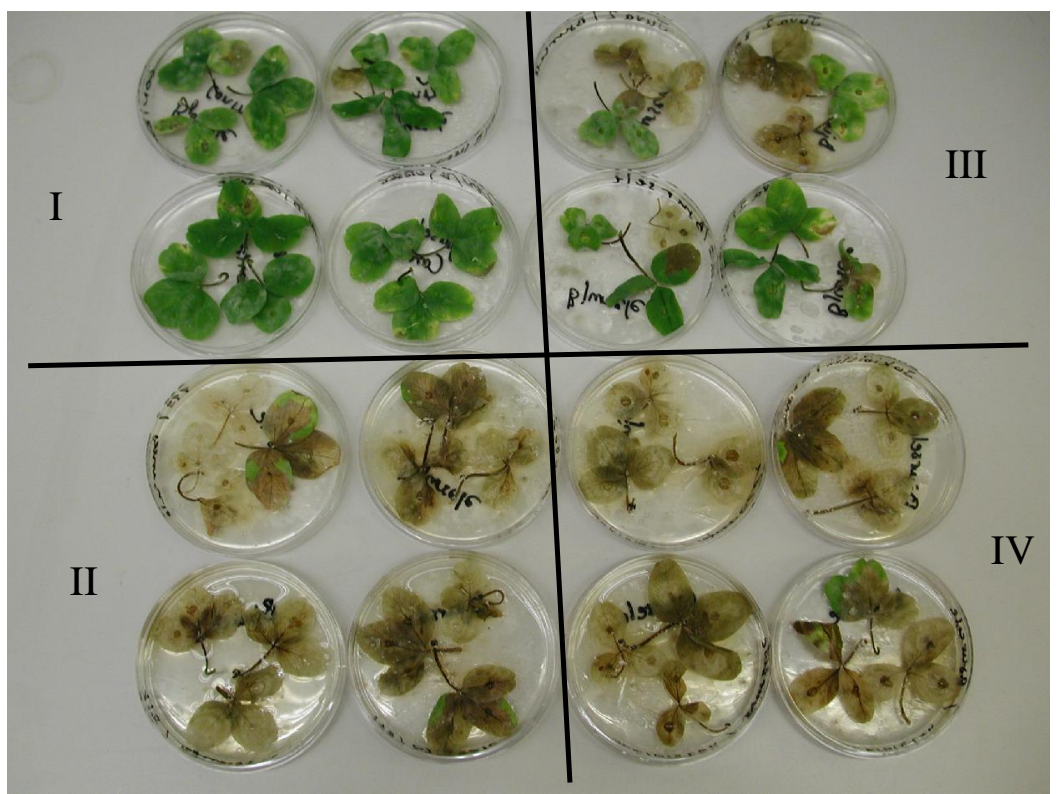

Kuva 5. Kolmen apilamätäkannan vaikutus Bjursele-lajikkeeseen kahden viikon kuluttua ymppäyksestä. I on kontrolli, II = Lappi-119, III = Juva-2, IV = Kainuu-1. Juva-2 osoittautui vähiten patogeeniseksi ja osa lehdistä on vielä vihreitä. 


\begin{tabular}{|c|c|c|c|c|}
\hline Käsittely & $\mathrm{DI}(\bar{x} \pm \mathrm{s} \bar{x})$ & $\begin{array}{l}\text { \% sairaita } \\
(\bar{x})\end{array}$ & $\begin{array}{l}\% \text { kuolleita } \\
(\bar{x})\end{array}$ & $\begin{array}{l}\text { Biologinen teho } \\
(\%)\end{array}$ \\
\hline \multicolumn{5}{|l|}{ Kontrolli } \\
\hline & $\begin{array}{r}\mathbf{0 , 9 7} \pm \mathbf{0}, \mathbf{3 5} \\
(1,9 \pm 0,52)\end{array}$ & $\begin{array}{c}\mathbf{6 6 , 7} \\
(80,0)\end{array}$ & $\begin{array}{l}\mathbf{0} \\
(0)\end{array}$ & - \\
\hline \multicolumn{5}{|l|}{119} \\
\hline & $\begin{array}{l}\mathbf{2 , 9 3} \pm \mathbf{0} \mathbf{0 , 1 8} \\
(3,7 \pm 0,25)\end{array}$ & $\begin{array}{l}\mathbf{9 3 , 3} \\
(93,3)\end{array}$ & $\begin{array}{l}\mathbf{3 3 , 3} \\
(86,7)\end{array}$ & - \\
\hline \multirow{2}{*}{ Mycostop+119 } & & & & $0(0)(\mathrm{DI})$ \\
\hline & $\begin{array}{l}\mathbf{3 , 1 0} \pm \mathbf{0 , 4 9} \\
(4,0)\end{array}$ & $\begin{array}{l}\mathbf{1 0 0 , 0} \\
(100)\end{array}$ & $\begin{array}{r}\mathbf{4 6 , 7} \\
(100)\end{array}$ & $\begin{array}{l}0(0)(\% \text { kuolleita } \\
\text { kasveja) }\end{array}$ \\
\hline \multirow[t]{2}{*}{ Prestop+119 } & & & & $0(0)(\mathrm{DI})$ \\
\hline & $\begin{array}{l}\mathbf{2 , 9 3} \pm \mathbf{0}, \mathbf{2 7} \\
(4,0)\end{array}$ & $\begin{array}{l}\mathbf{1 0 0 , 0} \\
(100)\end{array}$ & $\begin{array}{l}\mathbf{3 3 , 3} \\
(93,3)\end{array}$ & $\begin{array}{l}0(0)(\% \text { kuolleita } \\
\text { kasveja) }\end{array}$ \\
\hline \multirow[t]{2}{*}{ Alirin } & & & & $48(0)(\mathrm{DI})$ \\
\hline & $\begin{array}{l}\mathbf{1 , 5 3}+\mathbf{0} \mathbf{0 , 3 5} \\
(3,7 \pm 0,23)\end{array}$ & $\begin{array}{l}\mathbf{8 0 , 0} \\
(100)\end{array}$ & $\begin{array}{l}\mathbf{6 , 7} \\
(73,3)\end{array}$ & $\begin{array}{l}80(15,5)(\% \\
\text { kuolleita kasveja }) \\
0(0)(\mathrm{DI})\end{array}$ \\
\hline Gliomix & $\begin{array}{r}\mathbf{3 , 1 0} \pm \mathbf{0} \mathbf{0 , 3 2} \\
(3,9 \pm 0,06)\end{array}$ & $\begin{array}{l}\mathbf{9 3 , 3} \\
(100)\end{array}$ & $\begin{array}{l}\mathbf{5 8 , 0} \\
(86,7)\end{array}$ & $\begin{array}{l}0(0)(\% \text { kuolleita } \\
\text { kasveja) }\end{array}$ \\
\hline Rovral & 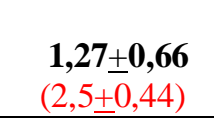 & $\begin{array}{r}\mathbf{5 3 , 3} \\
(100)\end{array}$ & $\begin{array}{c}\mathbf{6 , 7} \\
(6,7)\end{array}$ & $\begin{array}{l}57(32)(\mathrm{DI}) \\
80(92)(\% \\
\text { kuolleita kasveja) }\end{array}$ \\
\hline
\end{tabular}

Taulukko 2. Biopreparaattien biologinen teho keinotekoisesti apilamädällä saastutetuilla apiloilla verrattuna kemialliseen fungisidiin (Rovral) ja vesikontrolliin. Tulokset on mitattu kahden ja neljän (punainen arvo suluissa) viikon kuluttua saastutuksesta. Tulokset ovat kolmen käsittelyn (5 kasvia/käsittely) keskiarvoja.

\section{Kirjallisuus}

Hakala, K. \& Jauhiainen, L. 2006. Lajikevalinta ja viljelytoimet avaimina apilanviljelyn menestykseen. Maataloustieteen päivät 2006. www.smts.fi.

Holst-Jensen, A., Vaage, M. \& Schumacher, T. 1998. An approximation to the phylogeny of Sclerotinia and related genera. Nordic J. Bot. 18: 705-719.

Maatilan Pirkka 2/2000. Betty nykäisee apilasadot uudelle tasolle.

Marum P., Smith R.R. \& Grau C.R. 1994. Development of procedures to identify red clover resistant to Sclerotinia trifoliorum. Euphytica 77: 257-261.

Paavanen-Huhtala, S., Hyvönen, J., Bulat, S.A. \& Yli-Mattila, T. 1999. RAPD-PCR, isozyme,rDNA RFLP and rDNA sequence analyses in identification of Finnish Fusarium oxysporum isolates. - Mycol. Res. 103: 625-634.

Wallenhammar, A.-C., Adolfsson, E.., Engström, M., Henriksson, M., Lundmark, S., Rompke, G. \& Ståhl, P, 2005. Field Surveys of Fusarium root root in organic red clover leys. Abstract book of the NJF-Seminar 369 Organic Farming for a New Millenium, Alnarp, Sweden June 15-17, 2005: 197-199.

Ylimäki, A. 1967. Root rot as a cause of red clover decline in leys in Finland. Ann. Agric. Fenniae, 6, $1-59$.

Ylimäki, A. 1969. Apilamätä apilan talvehtimisen heikentäjänä Suomessa (Clover rot as a cause of poor overwintering of clover in Finland). J. Sci. Agric. Soc. Finland, 41, 222-242.

Yli-Mattila, T., Kalko, G., Hannukkala, A. \& Hakala, K. 2005. Clover rot (Sclerotinia trifoliorum) and Fusarium fungi in organic red clover in Finland. Abstract book of NJF-Seminar 369 Organic Farming for a New Millenium, Alnarp, Sweden June 15-17, 2005: 258.

Yli-Mattila, T., Paavanen, S., Hannukkala, A., Parikka, P., Tahvonen, R. \& Karjalainen, R 1996. Isozyme and RAPD-PCR analyses of Fusarium strains from Finland. Plant Pathol. 45: 126-134.

Yli-Mattila, T., Paavanen-Huhtala, S., Parikka, P., Hietaniemi, V., Jestoi, M., Gagkaeva, T., Sarlin, T., Haikara, A., Laaksonen, S. \& Rizzo, A. 2005. Real-time PCR deteection and quantification of Fusarium poae, $F$. graminearum, $F$. sporotrichioides and $F$. langsethiae as compared to mycotoxin production in grains in Finland and Russia Eur. J. Plant Pathol. (submitted). 